\title{
Terpenes from essential oils and hydrolate of Teucrium alopecurus triggered apoptotic events dependent on caspases activation and PARP cleavage in human colon cancer cells through decreased protein expressions
}

\author{
Fatma Guesmi ${ }^{1,2}$, Amit K. Tyagi ${ }^{1}$, Sahdeo Prasad ${ }^{1}$ and Ahmed Landoulsi ${ }^{2}$ \\ ${ }^{1}$ Department of Experimental Therapeutics, University of Texas MD Anderson Cancer Center, Houston, TX, USA \\ ${ }^{2}$ Laboratory of Biochemistry and Molecular Biology, Faculty of Sciences of Bizerte, University of Carthage, Tunis, Tunisia \\ Correspondence to: Fatma Guesmi, email: guesmif10@gmail.com \\ Keywords: Teucrium alopecurus; oily fractions; water soluble fractions; human colon cancer cells; gene expression \\ Received: February 23, $2018 \quad$ Accepted: July 29, $2018 \quad$ Published: August 17, 2018 \\ Copyright: Guesmi et al. This is an open-access article distributed under the terms of the Creative Commons Attribution License \\ 3.0 (CC BY 3.0), which permits unrestricted use, distribution, and reproduction in any medium, provided the original author and \\ source are credited.
}

\section{ABSTRACT}

This study focused on characterizing the Hydrophobic and Hydrophilic fractions of Teucrium alopecurus in the context of cancer prevention and therapy. The goal was also to elucidate the molecular mechanisms involved and to determine its efficacy against cancer by triggering apoptosis and suppressing tumorigenesis in human colon cancer. The data here clearly demonstrated that oily fractions of Teucrium alopecurus act as free radical scavengers, antibacterial agent and inhibited the proliferation of HCT-116, U266, SCC4, Panc28, KBM5, and MCF-7 cells in a time- and concentrationdependent manner. The results of live/dead and colony formation assays further revealed that Teucrium essential oil has the efficacy to suppress the growth of colon carcinoma cells. In addition, essential oil of Teucrium alopecurus induced apoptosis, as indicated by cleavage of caspases-3, -8 , and -9 and poly-adenosine diphosphate ribose polymerase. Moreover, Teucrium alopecurus essential oil suppressed gene expression involved in survival, proliferation, invasion, angiogenesis, and metastasis in human colon cancer cells. No sign of toxicity was detected in vivo after treatment with increasing concentrations of essential oil. Oral administration of T.alopecurus inhibited LPS-induced colon inflammation. This anticancer property of this specie Teucrium alopecurus fractions could be due to their phenolic and/or sesquiterpene content (D-limonene, a-Bisabolol, Humulene, Thymol, and (+)-epi-Bicyclosesquiphellandrene). Hence our study reveals the anticancer activity of Teucrium alopecurus oil mediated through the suppression of cell growth, cell proliferation, and the induction of apoptosis of cancer cells. Thus, it has potential to be developed as an anticancer agent; however more in vitro and in vivo studies are warranted.

\section{INTRODUCTION}

Colonic carcinoma, a multistage process that occurs over many years and is regulated by multiple signaling pathways, is the target of numerous anticancer therapies [1]. This disease involves many proteins until the first step of the tumor to the ultimate stade. The combination of chemotherapeutic drugs with terpenes could be of great clinical importance in cancer therapy [2]. Colorectal cancer (CRC), one of the most lethal cancers, especially when it reaches advanced stages [3] and develops resistance to chemotherapeutic agents over time [4], evolves through a multistep process in which normal mucosa is first transformed into adenomatous polyps and then eventually into invasive carcinoma [5]. Colon carcinogenesis progresses over many years via molecular events by the modification of genetic sequences, called as the adenoma-carcinoma sequence [6]. Genetic 
alterations in somatic cells (mutations) include the upregulation of proto-oncogenes and the down-regulation of tumor suppressor genes [7].

Using essential oils (EOs) from aromatic plants is one traditional alternative method that has been reported to have anticancer properties $[8,9]$, both in vitro and in vivo [10], against mouth, breast, lung, prostate, liver, colon, and brain cancer and even leukemia [11-16]. Numerous nutraceuticals from "mother nature" could be potential treatments for CRC [5]. These nutraceuticals target various steps in tumor cell development [1] and have been shown to potentially halt cancer progression by targeting one or more steps in the cell cycle [5]. Many researchers have demonstrated the anticancer effect of essential oils [17-21]. The chemical composition of essential oils can act as an anti-inflammatory, affecting arachidonic metabolism or cytokine production or the modulation of pro-inflammatory gene expression [22]. Natural products such as terpenes, a class of molecules characterized by the presence of multiple terpenic groups in their structural moiety, have emerged as alternatives to treat a broad range of human diseases, including particularly cancer and inflammation [23]. The whole botanical may be better than its active principle [5].

The Teucrium (Lamiaceae) genus contains many species that are distributed mainly in the Mediterranean basin [24]. Phenolic and terpenic components extracted from Teucrium species possess the ability to treat obesity, hypercholesterolemia, and diabetes, as well as antiinflammatory, antimicrobial, and anticancer properties [25]. T. polium protects liver cells against hepatocellular carcinoma in carcinogenesis-induced animal models [26]. It has been shown to be an effective and safe chemosensitizer agent for cancer therapy [25].

This report describes novel insight into the curative effect of hydrophobic fraction of Teucrium on cancer. Teucrium alopecurus (H'chichit ben salem), widely used in traditional medicine, is known to possess anti-inflammatory properties. The chemical investigation of the aerial parts has yielded bioactive compounds. Earlier studies showed that some of these compounds inhibit the proliferation of tumor cells. Our goal in this report was to investigate the possible use of essential oil (TA-1) and hydrolate (TA-2) of Teucrium alopecurus as an alternative complementary cancer treatment, and, in order to elucidate its potential activity and the mechanisms underlying these effects, this species was tested on colorectal carcinogenesis in vitro.

\section{RESULTS}

\section{Analysis of hydrophobic and hydrophilic fractions with gas chromatography-mass spectrometry (GC/MS)}

The essential oils and hydrolats of the aerial parts of Teucrium alopecurus were analysed qualitatively and quantitatively. Forty-eight compounds were identified and listed in Supplementary Table 1 and Supplementary Figure 1. Essential oil from Teucrium alopecurus showed that sesquiterpenes are the most abundant skeletons. Figure $1 \mathrm{Ai}$ shows that TA-1 is mainly composed of (+)-epiBicyclo sesquiphellandrene, $\alpha$-Bisabolol, T-Muurolol, $\alpha$-Cadinol, $\beta$ - Phellandrene, and D-limonene (Figure 1(Ai)). Of these terpene compounds, the most abundant was $\alpha$-Bisabolol (16.16\%). However, organic compounds were the only components of TA-2 (Figure 1(Aii)). It was noted that a small amount of essential oil was dissolved in the hydrosol. Distillation with a Clevenger apparatus completely extracted the essential oils and led to no loss of volatile molecules from Teисrium alopecurus.

\section{Phenolic contents}

As indicated in Figure 1Bi, phytochemical study indicated an important level of phenolic contents, including total phenols and Flavonoids.

\section{TA-1 and TA-2 scavenge free radicals}

It has been reported in Figure 1Bii and Figure 1Biii that Teucrium specie is indicated as potent free radical scavengers of the DPPH radicals and can also reduce the $\mathrm{Fe}^{3+} /$ ferricyanide complex to the ferrous form, the antioxidant effect is close to that of the standard ascorbic acid and BHT.

\section{Antibacterial activity of TA-1}

As reported in Figure 1C, essential oil isolated from Teucrium alopecurus was more effective $(P<0.05)$ in inhibiting all tested bacteria, than those of Chloramphenicol $(10 \mu \mathrm{g} / \mu \mathrm{l})(\mathrm{CFM})$ and Ertapenem $(10 \mu \mathrm{g} / \mu \mathrm{l})$ (ERTA).

\section{Cell viability of RAW 264.7 macrophage}

As shown in Figure 1D, MTT assay did not show any significant difference $(P>0.05)$ in RAW 264.7 cell viability among the control and TA-1 or TA-2-treated groups, this indicated that Teucrium alopecurus is not cytotoxic.

\section{TA-1 and hydrophilic fraction (TA-2) represses the proliferation of colorectal cancer cells}

Figure $1 \mathrm{E}$ shows the concentration- and timedependent repression of tumour cell proliferation induced by Teucrium. Breast cancer cells (MCF-7) and pancreatic carcinoma (Panc28) cells are the most sensitive to TA-1 at 5 and $10 \mathrm{pg} / \mathrm{mL}$ between three and five days and present low cell growth compared to the vehicle control (Figure 1E, upper panel). Chronic myelogenous leukemia (KBM-5) and human colon cancer cells (HCT116) cells have a moderate sensitivity to this essential oil. In addition, TA-2 suppresses the proliferation of cancer cells (Figure 1D, lower panel). 


\section{Teucrium fractions decrease clonogenic potential}

Treatment with hydrophobic and hydrophilic fractions of Teucrium suppresses the clonogenic potential of colon cancer cells. HCT-116 cell lines were very resistant to low and high concentrations of TA-2, showing only $\sim 5 \%$ reduction in clonogenic potential (Figure $2(\mathrm{Ai})$ ). However, treatment with a high concentration of TA-1 caused nearly $100 \%$ inhibition (Figure 2(Aii)). KBM5 cells were very sensitive to both high concentrations of TA-2 and various concentrations of TA-1.

\section{Teucrium induces radical oxygen species (ROS) generation}

The oily fraction of Teucrium alopecurus was able to induce ROS generation (Figure 2B). A significant $(p<0.05)$ increase in ROS levels at higher doses of $0.1 \mu \mathrm{g} / \mathrm{mL}$ (MFI 125.4) and $0.2 \mu \mathrm{g} / \mathrm{mL}$ (MFI 142.4) TA-1 compared to the control (MFI 114.2) was observed in colon cancer cells (Left panel). However, very low amounts (non-significant) of ROS were produced in HCT-116 treated with hydrophilic fractions of teucrium (Right panel).

\section{Live/dead assay}

The treatment of various tumor cell cultures with TA-1 volatile oil and TA-2 hydrolate for $48 \mathrm{~h}$ induces a concentration-dependent decreased cell number, but each cell line showed different sensitivity (Figure 3). Exposing different tumor cells to various concentrations of oily (Left panel) and soluble fractions (Right panel) of teucrium induced cell death in a concentration-dependent manner

A

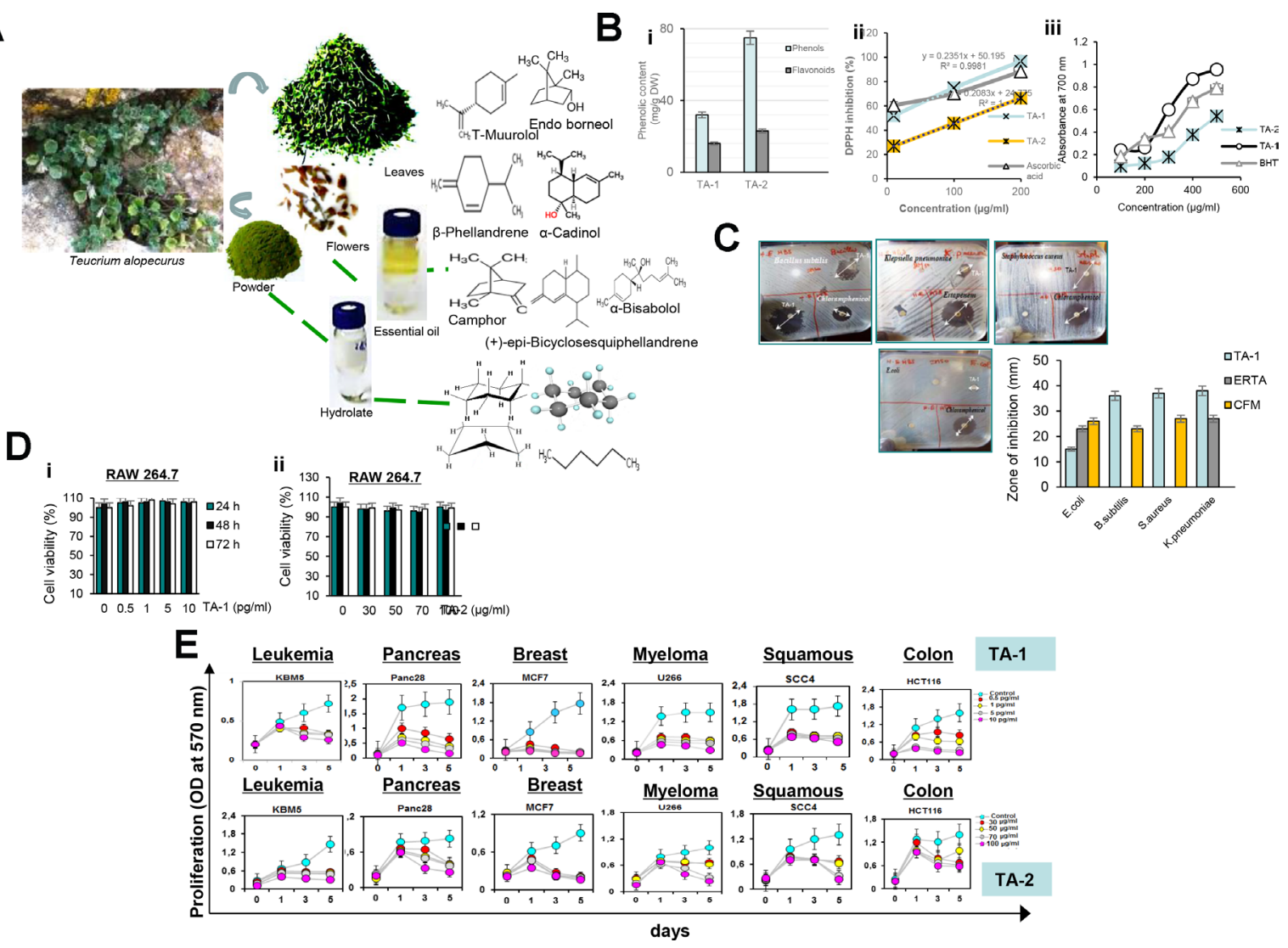

Figure 1: (A) Chemical structures of the major compounds of Hydrophobic (TA-1) (i) and Hydrophilic (TA-2) (ii) fractions of Teucrium alopecurus; (B) Phenolic content (i) and antiradical potential of TA-1 and TA-2 using DPPH (ii) and FRAP (iii) assay; (C) Antibacterial activity of hydrophobic fraction of Teucrium alopecurus. Plant essential oil (1 $\mu \mathrm{l})$ were applied per disc (Whatman No $5 \mathrm{~mm}$ ) onto the seeded top layer of the agar plates containing tested bacteria (E.coli, S.aureus, B.subtilis and K.pneumoniae). Essential oil was tested with a Chloramphenicol, and Ertapenem discs as positive controls. DMSO discs were used as negative controls. The plates were incubated at $37^{\circ} \mathrm{C}$ for $24 \mathrm{~h}$, and zone of inhibition was determined. (D) Effect of TA-1 and TA-2 on RAW cell viability. RAW 264.7 cells, seeded in triplicate in 96-well plates, were pre-treated with the concentrations of TA-1 $(0.5,1,5,10 \mathrm{pg} / \mathrm{mL})$ (i) and TA-2 $(30,50,70,100 \mu \mathrm{g} / \mathrm{mL})(\mathrm{ii})$ and incubated for $24 \mathrm{~h}, 48 \mathrm{~h}$ and $72 \mathrm{~h}$. Cell viability was analyzed with the MTT assay. (E) Effect of TA-1 and TA-2 on tumor cell proliferation. KBM-5, HCT-116, Panc-28, MCF-7, U266, and SCC4 cells $\left(5 \times 10^{3}\right.$ cells/well $)$ were seeded in triplicate in 96-well plates, treated with different concentrations of TA-1 $(0.5,1,5,10 \mathrm{pg} / \mathrm{mL})$ and TA-2 $(30,50,70,100 \mu \mathrm{g} / \mathrm{mL})$; cell growth was analyzed on days $0,1,3$, and 5 by tetrazolium salt 3-(4-5-dimethylthiozol-2-yl)2-5-diphenyl-tetrazolium bromide (MTT) assay. The results show the mean \pm SD values. These are representative results of three independent experiments. 
and significantly increased the number of apoptotic cells from $1 \%$ to $\sim 100 \%$ and from $1 \%$ to $80 \%$, respectively.

\section{Caspases activation and poly-adenosine diphosphate ribose polymerase (PARP) cleavage}

The different times and concentrations when exposing HCT-116 cells to teucrium essential oil indicate that this essence protects the cells from DNA degradation. The results above show that Teucrium induced significant caspase activation and PARP cleavage in a concentrationand time-dependent manner (Figure 4 (Ai-Aii) and 4B), thus indicating that colorectal cancer cells are undergoing apoptosis.

As shown in Figure 4Aiii, Teucrium alopecurus did not induced PARP cleavage in human umbilical vein endothelial cells (HUVECs), this indicated that essential oil is not cytotoxic to normal cells.

\section{TA-1 and TA-2 suppress the expression of gene products involved in the antiapoptotic, proliferation, metastasis, invasion and angiogenesis of colorectal cancer cells}

The down-regulation of multiple gene products obtained from the western blot analysis of the TA-1 effect explains a molecular mechanism of blocking gene expression in response to teucrium essential oil treatment in a concentration-dependent (Figure 5 (Ai-Aiii)) and time-dependent (Figure 5 (Bi-Biii)) manner. As shown in Figure 5Av, no expression of gene products in HUVECs cells was detected after treatment with TA-1. Western blotting and relative densitometric analyses of the suppression of antiapoptotic, proliferative, and metastatic gene products and the inhibition of Signal transducer (STAT3) phosphorylation cellular levels by TA-1 essential oil in HCT-116 cell lines at different concentrations and
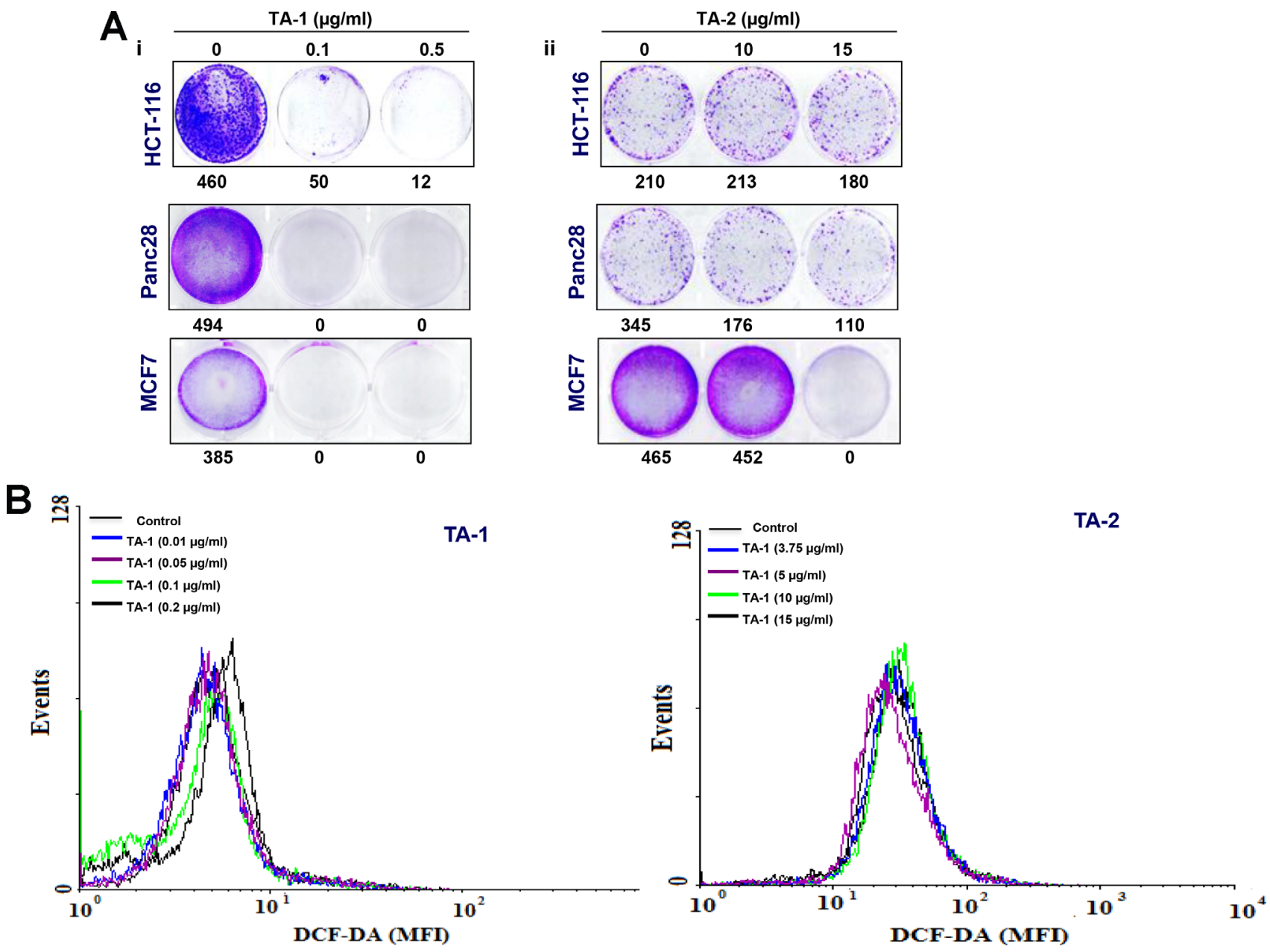

Figure 2: (A) Effects of TA-1 and TA-2 on the clonogenic potential of tumor cells; cells were plated in six-well plates in FBS-containing medium, then exposed to different concentrations of TA-1 and TA-2. At this point, the drug treatments were washed out and replaced with fresh medium. The ability of individual cells to form colonies was assessed 9 days posttreatment. (B) TA-1 induces ROS production. HCT-116 $\left(1 \times 10^{6}\right.$ cells $)$ were labeled with dichlorodihydrofluorescein diacetate (DCF-DA), treated with the concentrations of TA-1 and TA-2 indicated for $1 \mathrm{~h}$, and then examined for ROS production by flow cytometer. ${ }^{*}$ is the significance of difference compared with vehicle control; $p<0.05$. These are representative results of three independent experiments. 
time points are shown in Supplementary Figure 2. Blots have been done three times.

As shown in Figure 5 (Bi, Bii) the c-myc as cell cycle components and the cell cycle regulator protein (cyclin D1)were down-expressed within $6 \mathrm{~h}$ of teucrium essential oil treatment, whereas Intercellular adhesion molecule-1 (ICAM1), an inhibitor of apoptosis protein (IAP)-1, IAP-2 proteins were not down-regulated, even after $12 \mathrm{~h}$ of treatment in HCT-116 cells. Complete abrogation of most gene expression appeared upon treatment with $100 \mathrm{pg} / \mathrm{mL}$ TA-1.

There was a low concentration-dependent decrease in the expression of various genes upon hydrosol treatment, with the maximal inhibition effect observed at $15 \mu \mathrm{g} / \mathrm{mL}$ (Figure 5 (Ci, Cii)).

\section{TA-1 suppresses constitutive STAT3 activation in HCT-116 cells}

Colorectal cancer cells express constitutively active STAT3 [27]. Upon exposing tumor cells to various concentrations of essential oils, prepared cell lysates were investigated for the phosphorylation of STAT3 (Tyr ${ }^{705}$ ) and $\left(\mathrm{Ser}^{727}\right)$ and performed by western blot analysis.
Interestingly, these results show the concentration- and time-dependent repression of STAT-3 activation induced by TA-1 in HCT-116 cells (Figure 5 (Aiv, Biv)). The maximum inhibitory activity occurred at $100 \mathrm{pg} / \mathrm{mL}$, and the optimum time for the repression of STAT3 phosphorylation was at $24 \mathrm{~h}$.

\section{Acute cytotoxic effect of TA-1}

Figure 7 shows the pharmacological study of the general toxicity of essential oil in mice. TA-1 at different doses of 10, 20 and $30 \mu \mathrm{g} \mathrm{Kg}^{-1}$ exhibited no signs of toxicity (Figure 7A). Histological overview showed no abnormal damage in liver and kidney and any difference between treated and untreated groups (Figure 7B). After 7 days of observation, there were no mortality and no behavioural changes were detected.

\section{Anti-inflammatory effect of TA-1}

As shown in Figure 8, mice were treated with TA-1 low dose (LD) and high dose (HD) $1 \mathrm{~h}$ before treatment with lipopolysaccharide (LPS) (Escherichia coli 055:B5) as inflammatory agent (Figure 8A) used to induce

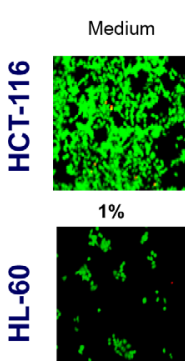

$1 \%$

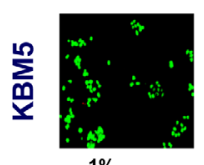

$1 \%$

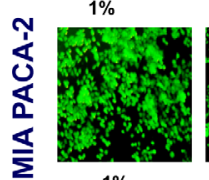

$1 \%$

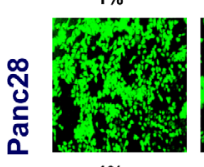

$1 \%$

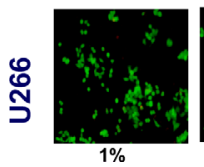

$1 \%$

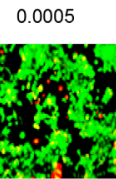

$22 \%$

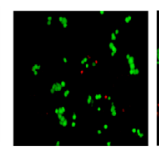

$10 \%$

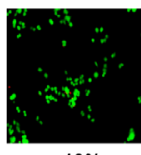

$13 \%$

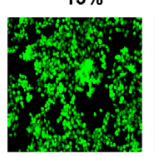

$7 \%$

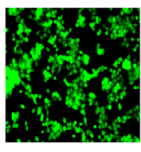

$2 \%$

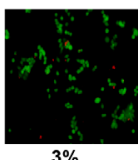

$3 \%$

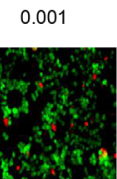

$27 \%$

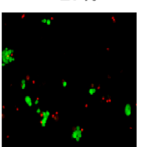

$23 \%$

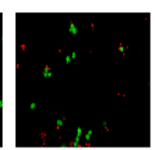

$33 \%$

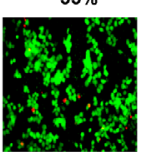

$24 \%$

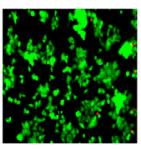

$10 \%$

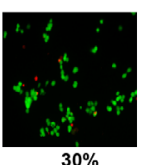

0.005
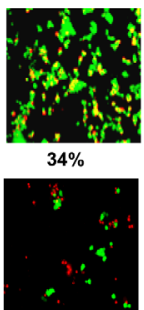

$29 \%$

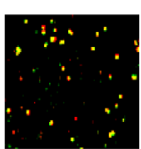

$42 \%$

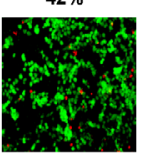

$36 \%$

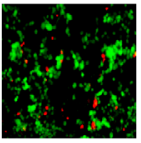

$57 \%$

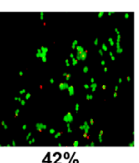

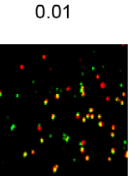

$56 \%$

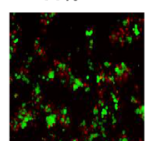

$74 \%$

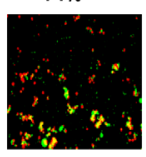

$58 \%$

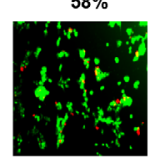

$42 \%$

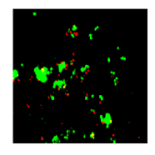

$62 \%$

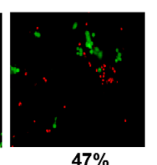

0.05 TA-1

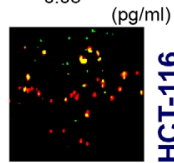

Medium

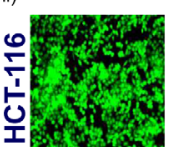

$82 \%$
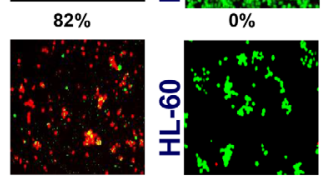

$91 \%$

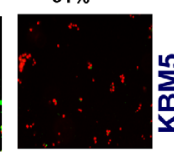

$1 \%$

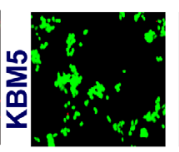

$94 \%$

$1 \%$

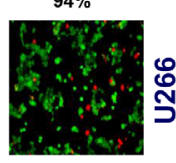

$68 \%$

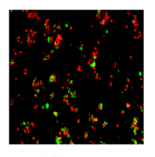

$87 \%$

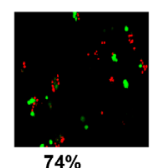

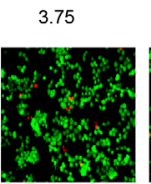
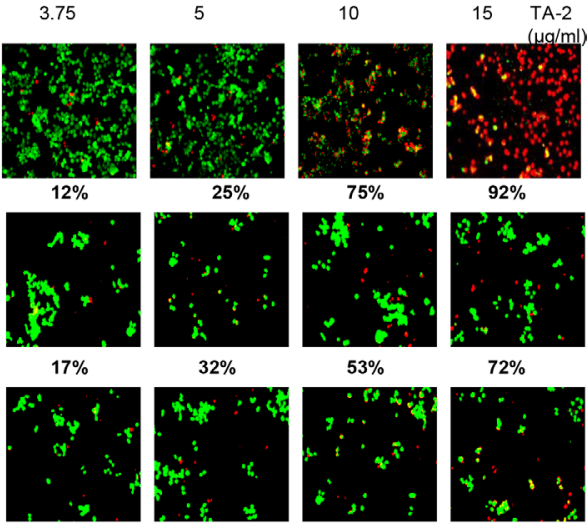

$32 \%$
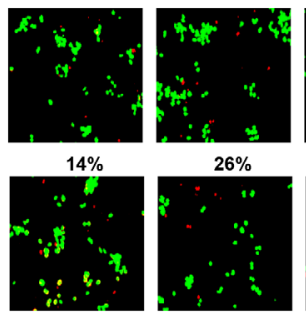

$24 \%$

$20 \%$

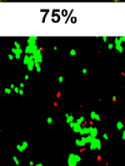

$92 \%$

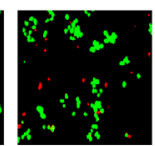

$53 \%$

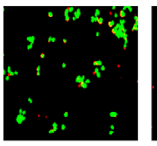

$72 \%$
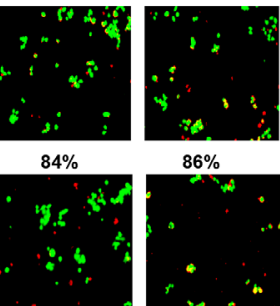

$82 \%$

Figure 3: Tumor cells were treated with different concentrations of TA-1 and TA-2. Cells were stained with the Live/Dead reagent ( $5 \mathrm{mM}$ ethidium homodimer and $5 \mathrm{mM}$ calcein $\mathrm{AM}$ ) and incubated at $37^{\circ} \mathrm{C}$ for $30 \mathrm{~min}$. Cells were analyzed under a fluorescence microscope (Labophot-2; Nikon, Tokyo, Japan). Percentages are proportions of apoptotic cancer cells. The results are representative of three independent experiments. Viable cells are green and non-viable cells are red. Magnification $=20 \times$. 
inflammation and cancer in colon cells. After experimental analysis, LPS was shown to induce body weight loss (Figure 8B), inhibition of colon length (Figure 8C), inflammation in colon (Figure 8D) and other parts of digestive system (Supplementary Figure 4), which have an effect on weight and color of feces. In addition, LPS induced damage in spleen and lung tissues (Figure 8E) compared with control group. Whereas, the therapeutic effect of essential oil was clearly investigated. We have found that TA-1 could effectively decrease the damage of colon, spleen and lung cells compared with comparator control group $(5-\mathrm{Fu})$. The results indicated that 5-Fu could reduce the inflammation of colon cells which increased by LPS.

\section{DISCUSSION}

The aim of this study was to determine whether Teucrium essential oil led to antitumor activity by abrogating the STAT3 signaling pathway in colon cancer cells. An increased level of apoptotic CRC cells was observed, as well as inhibited proliferation using MTT and Live/Dead assays.
Natural bioproducts are invaluable resources in drug discovery [28]. Many reports have documented the antitumor effects of essential oils and their bioactive compounds. In the literature, it has been reported that muurolol, $\delta$-cadinene, and spathulenol $[22,29]$ are the most abundant bioactive compounds of essential oils extracted from the aerial parts of some species belonging to the genus Teucrium (T. brevifolia Schreber, T. montbretii Benth. ssp. heliotropiifolium (Barbey) Davis, T. flavum, and $T$. capitatum). In our work, $1.78 \%$ of $\delta$-cadinene in TA-1 leaves was found, whereas there was a low amount of tau.-Muurolol.

Previous reports on the chemical composition of Teucrium alopecurus essential oil growing in Tunisia showed sesquiterpenes, mainly $\delta$-cadinene $(13.4 \%)$, $\alpha$-humulene $(12.3 \%)$, and nerolidyl acetate (12.3\%), as its major components [30]. There is also data in the literature about the most abundant fatty acids, where Linolenic, linoleic, and palmitic acids together made up $74.2 \%$ of Teucrium alopecurus collected from Matmata, Gabes (Tunisia), and the highest number of sterols were stigmasterol, sitosterol, phytosterol, and clerosterol [31].
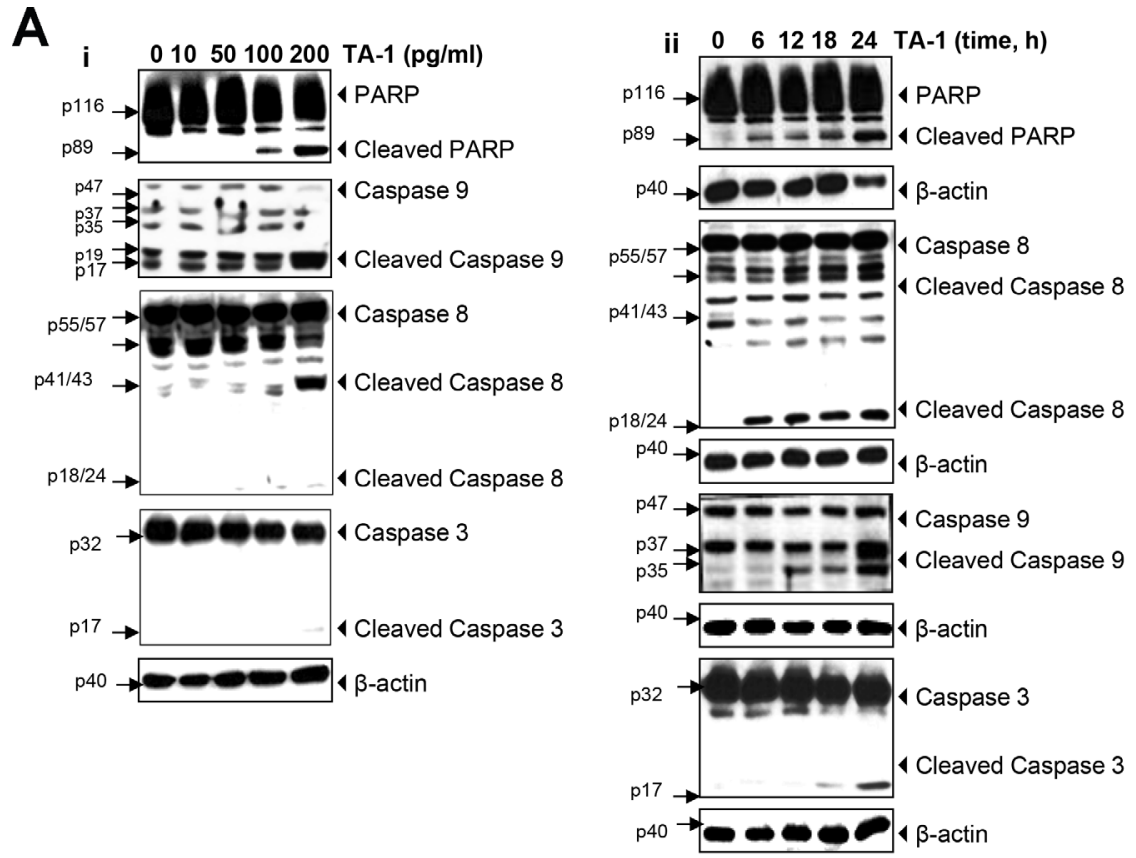

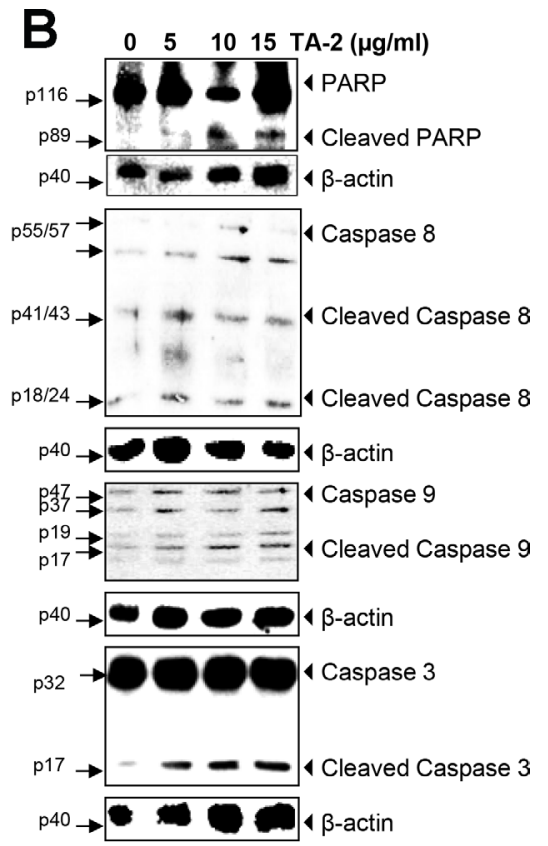

iii

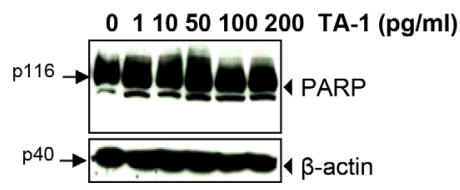

Figure 4: TA-1 and TA-2 induces caspase activation and poly-adenosine diphosphate ribose polymerase (PARP) cleavage in HCT-116 cells in a concentration- and time-dependent manner. (A) Whole-cell extracts of HCT-116 and HUVECs cells were treated with different concentrations of TA-1 and then analyzed by Western blotting using the antibodies indicated and (B) HCT116 Cells were treated with $200 \mathrm{pg} / \mathrm{mL}$ TA-1 for the indicated times, and whole cell extracts were prepared and analyzed using the indicated antibodies. These are representative results of three independent experiments. 
The cytotoxic effects exhibited by essential oils could be related to an overall action of the compounds present in oils, especially to sesquiterpene compounds $[32,33]$, phenols, alcohols, and monoterpene aldehydes $[34,35]$. TA-1, with its bioactive compounds, and hydrosol elicit a cytotoxic effect by inhibiting cell viability. In the study done by El Hadri et al. [36], $\alpha$-humulene was found to be cytotoxic against MCF-7, HCT-116, and murine macrophage (RAW264.7) cell lines. The cytotoxic potential of $\beta$-pinene was investigated in MCF-7, A375, and HepG2 cancer cells and in other different tumor and nontumor cell lines [37]. In fact, the studies of the cytotoxicity of cancer cell lines towards essential oils demonstrate a great difference between them with respect to their sensitivity to the substances contained in the oily fraction [38] of TA-1.

Various cell cycle checkpoints act as potential targets for cancer treatment [10]. Several nutraceuticals prevent cancer cells from transitioning from the G1 to $\mathrm{S}$ phase. EOs and their constituents serve as effective anticancer substances by targeting cell cycle progression in cancer cells [10]. In colorectal cancer cells, the maximal alteration in cancer cell cycle progression in the G2/M phase promoted by TA-1 was observed at $24 \mathrm{~h}$. Volatile oils and their constituents serve as effective anticancer substances by targeting cell cycle progression in cancer cells [10]. Thymol, a phenolic compound of Teucrium essential oil, induced cell cycle arrest at the G0/G1 phase [39]. Gene products involved in cell proliferation were found here to be overexpressed in HCT116 cells. Hydrophobic and hydrophylic fractions decreased cell proliferation in human colon cancer cells through a decrease of Cyclin D1 and p21.

Cancer cells possess several abilities like resistance to growth inhibition, proliferation without dependence on growth factors, replication without limit, evasion of the apoptosis, and the invasion, metastasize, and support of angiogenesis [1].

TA-1 and TA-2 were found here to suppress the proliferation of various types of tumor cells. Based on the data in the literature, it is possible to hypothesize that the antiproliferative effect of oily fractions was correlated with major terpenes constituents, $\alpha$-Bisabolol as a sesquiterpene alcohol, and (+)-epi-Bicyclosesquiphellandrene. In a further study on highly malignant glioma cells, Edris [20] evaluated that $\alpha$-Bisabolol is considered a promising inducer of apoptosis. According to the work of Tyagi et al. [40], $\beta$-sesquiphellandrene was found to have antiproliferative effects comparable to those of curcumin in human leukemia, multiple myeloma, and colorectal cancer cells. D-limonene, as a constituent of TA-1 in a small amount, is able to inhibit cell proliferation and enhance apoptosis [20]. Another
A

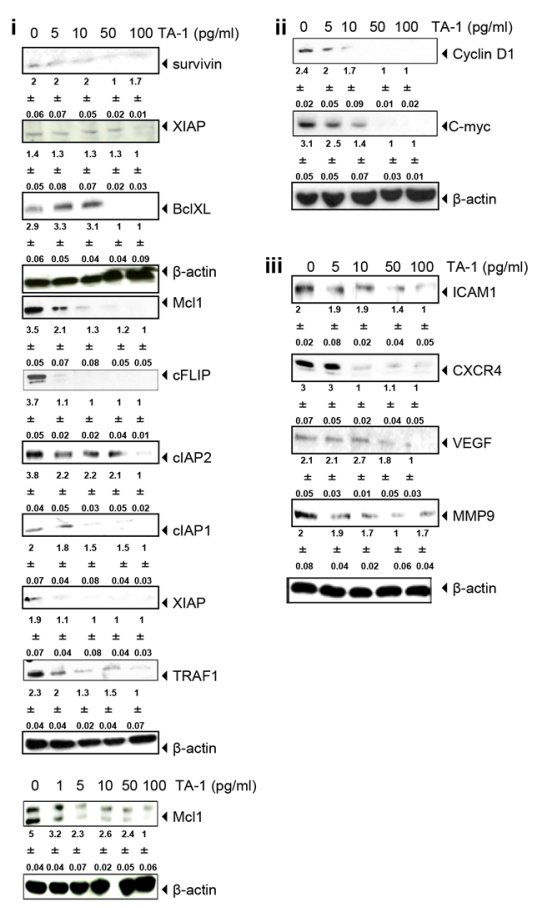

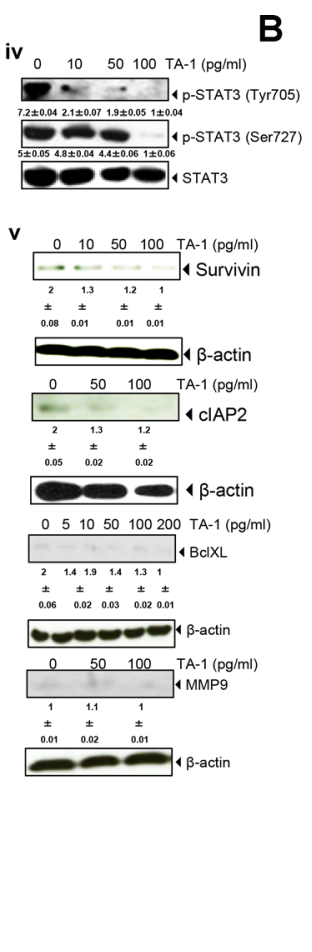

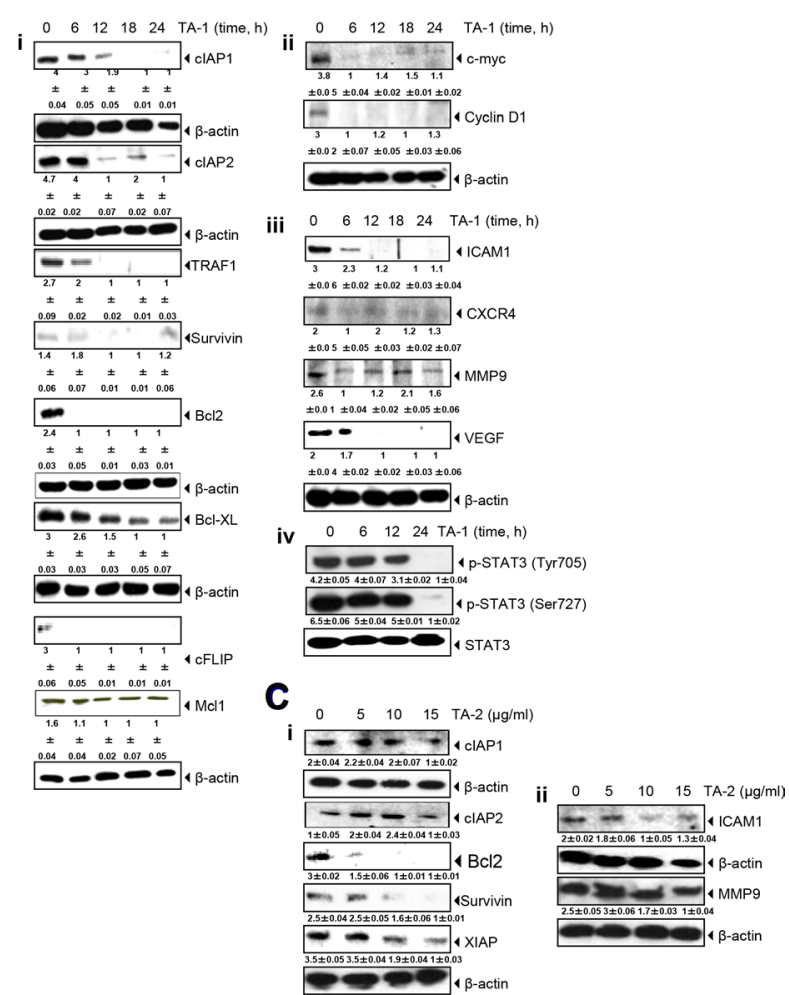

Figure 5: TA-1 suppresses (Ai, Bi) antiapoptotic, (Aii, Aiii, Bii, Biii) proliferative, and metastatic gene products and (Aiv, Biv) inhibits STAT3 phosphorylation in HCT-116 cell lines in a time- and concentration-dependent manner. TA-1 had no effect on HUVECs cells (Aiii). TA-2 suppresses (Ci) antiapoptotic and (Cii) metastatic gene products. The cells were treated with the concentrations of TA-1or TA-2 indicated for $24 \mathrm{~h}$. Whole cell protein extracts were prepared, separated by electrophoresis, and then transferred to the nitrocellulose membrane using the antibodies indicated. These are representative results of three independent experiments. 
sesquiterpene present in TA-1, namely $\lambda$-Humulene, has been identified for its pro-apoptotic activities, mainly against colorectal carcinoma [2].

A recent report by Escandary et al. [41] also investigated the antiproliferative activity of $T$. polium on different cell lines. T. polium has been shown to be an effective and safe chemosensitizer agent for cancer therapy [25].

It is interesting to note that inducing apoptosis depends on an extrinsic and intrinsic pathway. The intrinsic pathway is mitochondria dependent, whereas the extrinsic is triggered by death receptors (DRs) [1]. PARP-1 cleavage induced by derivative compounds of EOs contributes to the change of the DNA repair process in the cancer cells [10]. Proteolytic cleavage of PARP activated caspases and can be used to detect apoptosis [42]. TA-1 was found here to trigger an increase in the expression levels of cleavedPARP, as well as caspases-3, -8 and, -9 dependent increases in apoptosis. Caspases are activated by proteolytic processing at sites that are themselves caspase consensus cleavage sites [43]. An intrinsic pathway was activated in Limonene treated LS174T colon cancer cells [44].

Some EOs and their components inhibit tumor cell survival through caspase activation, the induction of proapoptotic proteins, and the downregulation of antiapoptotic proteins [1]. Activating caspase-8 is associated with FLICE/caspase-8 inhibitory protein (c-FLIP) decreasing after treatment with teucrium essential oil, which also inhibited the cell survival of HCT-116 cells by downregulating the expression of cyclin D1, myeloid cell leukemia (Mcl-1), X-chromosome-linked IAP (XIAP), IAP1, IAP-2, and B cell lymphoma extra large (BcL-xL) levels. $\mathrm{Bcl}-2$ protein is downregulated by the action of TA-1 on the HCT-116 cancer cells in a dose- and time-dependent manner. The results obtained here agreed with other reports that hydrophobic fractions extracted from many species are able to change the expression levels of $\mathrm{Bcl}-2$ and Bax genes in KB human oral epidermoid carcinoma cells [11].

Furthermore, apoptosis and proliferation are linked by cell cycle regulators [45]. TA-1 induces apoptosis by increasing the tumor suppressor $p 53$ as a G1 regulator. p53 activates specific transcriptional targets that control cell cycle arrest, DNA repair, angiogenesis, autophagy, metabolism, migration, aging, senescence, and apoptosis [46]. Without a functional $p 53$ gene, cells lack the DNAdamage-sensing capability that would normally induce the apoptotic cascade [1]. Similar data were reported by Gupta et al. [47] in three colon cancer cell lines (HCT-116, Caco-2, and HT-29) that were inhibited by a triterpene (nimbolide) by repressing the expression of tumorigenic proteins.

STAT3 undergoes phosphorylation from serine residues [48]. In general, exposure to TA-1 is required to suppress the constitutive activation of STAT- 3 (Figures 5(Aiv) and 7D) in HCT-116 cells. It can induce a decrease of phosphorylated signal transducers and the levels of activators of transcription protein STAT-3 (at $\mathrm{Tyr}^{705}$ and $\mathrm{Ser}^{727}$ ) in human colon cancer cells in a dose- and time- dependent manner. This data is supported by another report showing the ability of STAT-3 to phosphorylate in HCT116 cell lines [49]. STAT-3 is overexpressed in several tumor cells, including cholangiocarcinoma, breast cancer, prostate cancer, head and neck squamous cell carcinoma, lymphomas and leukemia, brain tumors, gastric cancer, esophageal cancer, ovarian cancer, nasopharyngeal cancer, and pancreatic cancer [27].

In addition, Teucrium ethereal oil was also tested to see whether it was able to express proteins involved in the angiogenic phenotypes of cancer cells on tumor invasion and the metastasis of human colon cancer cells in vitro by reducing $\mathrm{CXC}$ chemokine receptor 4 (CXCR4) levels and restoring vascular cell adhesion molecule 1 (VCAM-1) and matrix metalloproteinase (MMP-9) expression in a dose- and time-dependent manner, as compared with control cells. MMP9 and ICAM-1 participate in the proteolytic degradation of tissue barriers [1]. The inflammatory process is directly linked to the metastatic process [50], which depends on angiogenesis. The potent antiangiogenic effect of TA-1 investigated in HCT-116 was associated with significant inhibition of the protein expression level of anti-vascular endothelial growth factor (VEGF), thus suggesting that this drug is a potent suppressor of tumor invasion through its action on VEGF, which induces angiogenesis by binding to its receptor tyrosine kinase. Chidambara and co-workers [51] investigated the antiangiogenic effect of D-limonene with a preventative effect on colon cancer. Jung et al. [52] showed that epigallocatechin gallate (EGCG) attenuated VEGF production through the inhibition of ERK-1 and ERK-2 kinases in human colon cancer cells. c-myc as a cell cycle component is down-regulated by teucrium essential oil, and this inhibition leads to growth arrest.

TA-1 inhibited the proliferation, invasion, and metastasis of Panc28, Miapaca, and HL60 cancer cells by down-regulating Bcl-xL, XIAP, survivin, MMP-9, and CXCR4 expression (Figure 6A-6C). CXCR4, cooperate with chemokine receptor (CCR1 and/or CCR2) to promote metastasis-associated macrophage (MAM) accumulation and thereby metastatic tumor growth [53]. Supplementary Figure 3 shows a densitometry analysis of Western blots. Understanding structural and molecular mechanisms of anti-cancer agents can help in developing new and more potent drugs with fewer side effects [27]. Deb and co-workers [54] reported that thymol induced apoptosis in HL-60 cells via caspase-dependent and caspaseindependent pathways. A recent finding about D-limonene and elemene colon cancer treatment was obtained from LS174T and Lovo cells with akt and telomerase activity inhibition, respectively, cell cycle arrest, and apoptosis $[44,55]$. D-limonene induced apoptosis in HL-60 cells through the activation of caspase-8 [56]. In another report, bioactive compound, 7-O-pentyl quercetin (Q$7 \mathrm{P})$, induced apoptosis in tumoral cells and massive ROS production [57]. 
LPS is a major structural component of the outer membrane of Gram-negative bacteria and is a potent inducer of inflammation through the production of various cytokines, growth factors and inflammatory mediators [58]. It plays an important role in occurrence, development and metastasis of tumors [59]. Our data suggest that TA-1

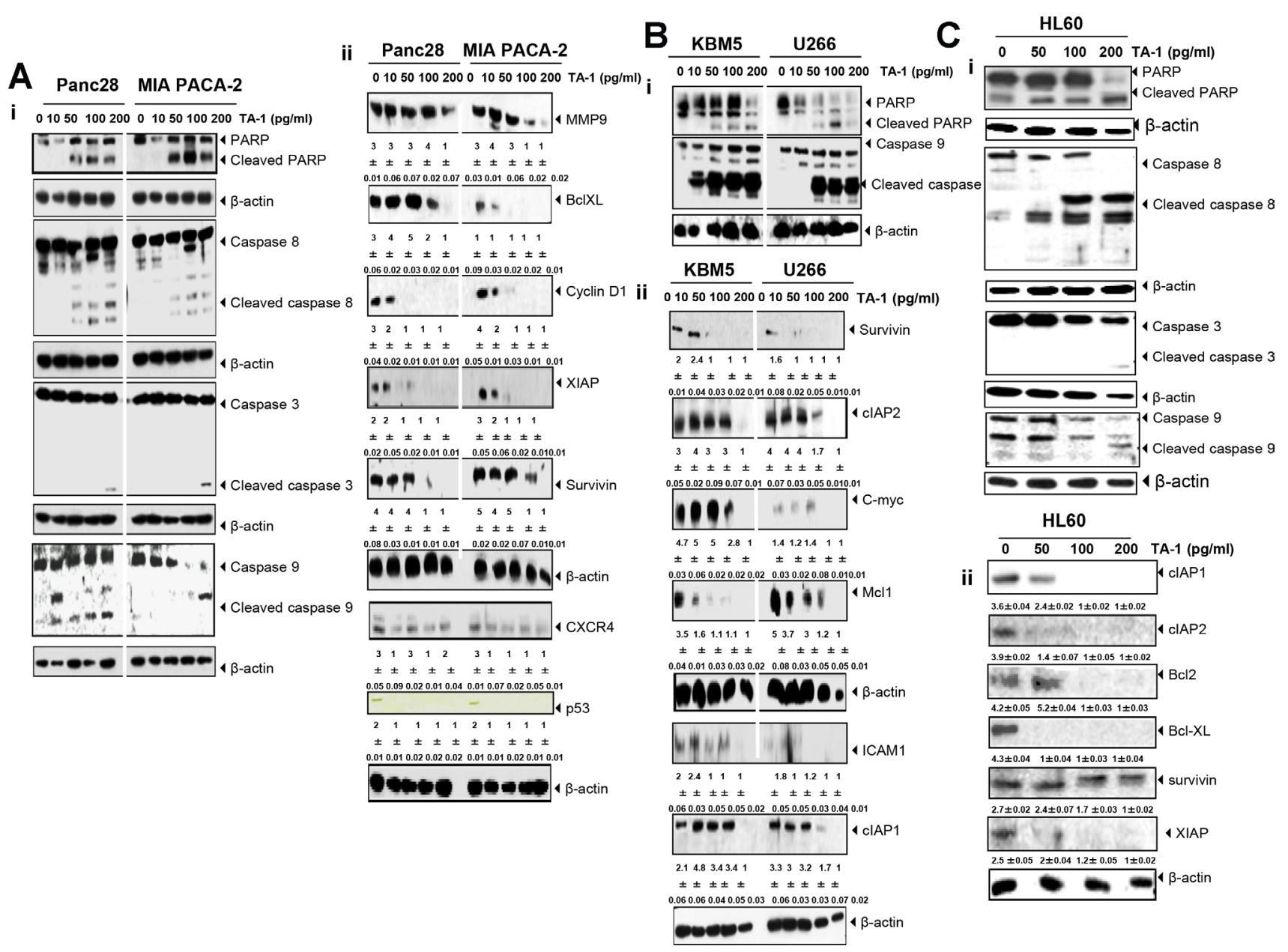

Figure 6: TA-1 induces PARP cleavage and caspases activation and suppresses the expression of gene products involved in tumor cell survival, proliferation, and metastasis in (A) Panc28- and MIA PACA-2 cells, (B) KBM5 and U266 cells, (C) and HL60 cells. The cells were treated with the concentrations of TA-1 indicated for $24 \mathrm{~h}$. Whole cell protein extracts were prepared, separated by electrophoresis, and then transferred to the nitrocellulose membrane using the antibodies indicated. These are representative results of three independent experiments.

A

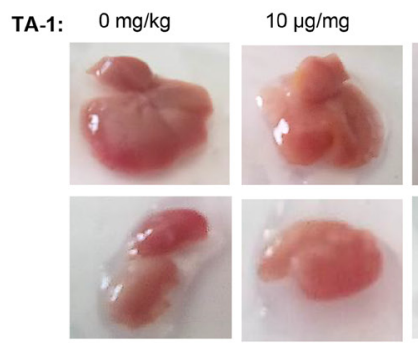

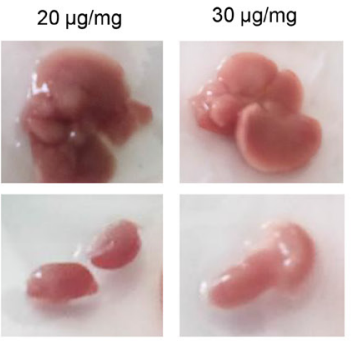

B

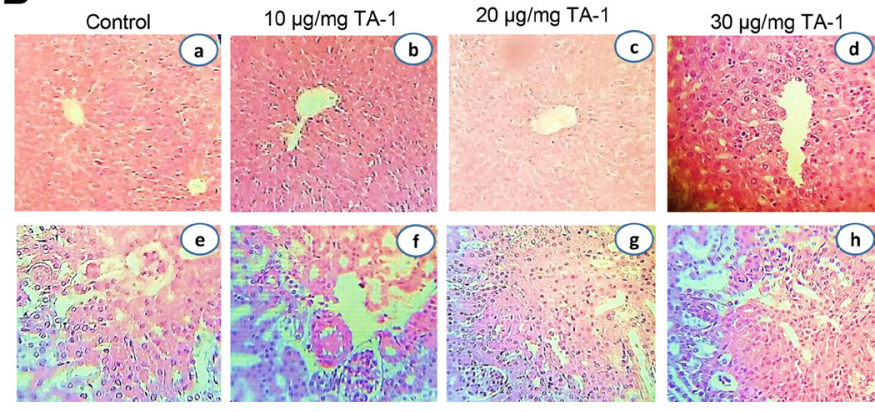

Figure 7: Macroscopical view of mice liver and kidney (A) and histological sections of liver and kidney from the acute toxicity test (B). No significant differences in the structure of liver and kidney between treated and control groups (Hematoxylin \& Eosin stain). Magnification: $\mathrm{a}, \mathrm{b}$ and $\mathrm{c}, \times 10$; d, e, f and $\mathrm{h} \times 40$. Data are represented as $\mathrm{x} \pm \mathrm{s}(n=6)$. 
act as a potential inhibitor for LPS-induced inflammation and damage of colon cells in vivo by decreasing the length of mice colon and body weight loss.

This study provides evidence for the therapeutic potential of Teucrium alopecurus essential oil to be used for the treatment of cancer. Thus, it up-regulates proapoptotic proteins and down-regulates cell survival, proliferation, invasion, angiogenesis, and metastasis in HCT-116 cells. Hydrolates obtained from this species have low potential as anti-cancer agents, and this may be due to low amounts of terpenes and phenolic compounds contained therein. Further studies in animals and humans will be required to demonstrate the relevance of these results obtained in vitro to cancer treatment. Essential oil of Teucrium is a potential therapeutic target for LPSinduced colon inflammation.

\section{Reagents}

Hydrophobic and hydrophilic fractions of Teucrium alopecurus leaves were characterized by gas chromatography-mass spectrometry (GC/MS). Stock solutions of oily $(100 \mu \mathrm{g} / \mathrm{mL})$ and water soluble fractions $(500 \mu \mathrm{g} / \mathrm{mL})$ were prepared in dimethyl sulfoxide (DMSO) and diluted as needed in a cell culture medium. Penicillin, streptomycin, Iscove's modified Dulbecco's medium
(IMDM), Roswell Park Memorial Institute medium (RPMI)-640 medium, Dulbecco's modified Eagle's medium (DMEM)/F12 medium and fetal bovine serum (FBS) were obtained from Mediatech, Inc. (Herndon, VA, USA). Bovine serum albumin (BSA) was purchased from Atlanta Biologicals (Norcross, GA, USA). NaCl, Tris, sodium dodecyl sulphate (SDS), MTT, and glycine, LPS (Escherichia coli 055:B5), the $\beta$-actin, butylhydroxytoluene (BHT), ascorbic acide (1\%), 2,2-diphényl1-picrylhydrazyl (DPPH), ferric reducing antioxidant power (FRAP), potassium ferricyanide $\left(\mathrm{K}_{3} \mathrm{Fe}(\mathrm{CN})_{6}\right)(1 \%)$, trichloro acetic acide (TCA) $(10 \%)$, ferric Chloride $\left(\mathrm{FeCl}_{3}\right)$ $(0.1 \%)$, CFM $(10 \mu \mathrm{g} / \mu \mathrm{l})$, and ERTA $(10 \mu \mathrm{g} / \mu \mathrm{l})$ were purchased from Sigma-Aldrich (St. Louis, MO, USA). Antibodies against c-Myc, CXCR4, MMP-9, cIAP-1/2, Mcl-1, ICAM-1, Bcl-xL, cyclin D1, caspases-3, -8, and -9, PARP, Bcl-2, STAT-3, and pSTAT3 (Tyr705 and Ser727) were obtained from Santa Cruz Biotechnology (Santa Cruz, CA, USA); the $\beta$-actin antibody was obtained from Sigma-Aldrich (St. Louis, MO, USA); X-linked IAP and c-FLIP antibodies were obtained from BD Biosciences and Imgenex (San Diego, CA, USA), respectively. Antibodies against survivin were obtained from R\&D Systems (Minneapolis, MN, USA); the VEGF antibody was purchased from NeoMarkers (Fremont, CA, USA); 5 -FU (purity $>99 \%$ ) was purchased from Sigma Chemical
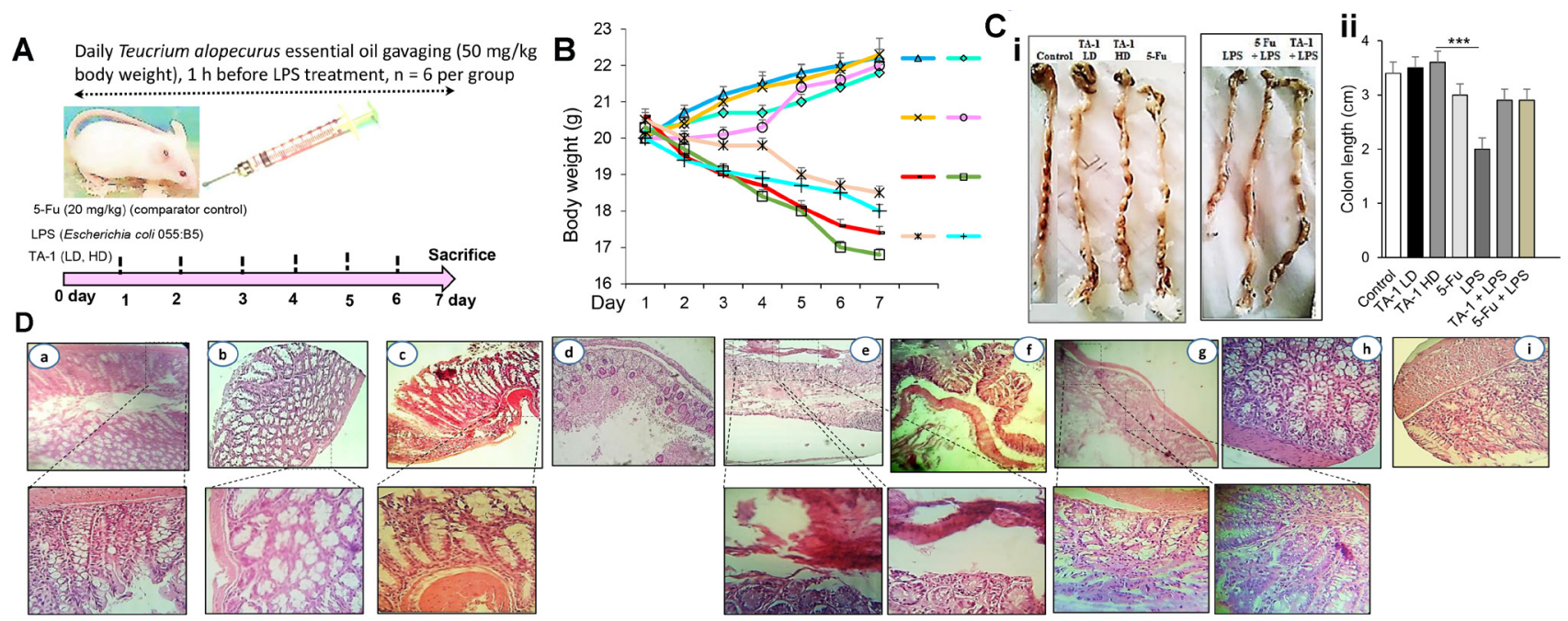

E
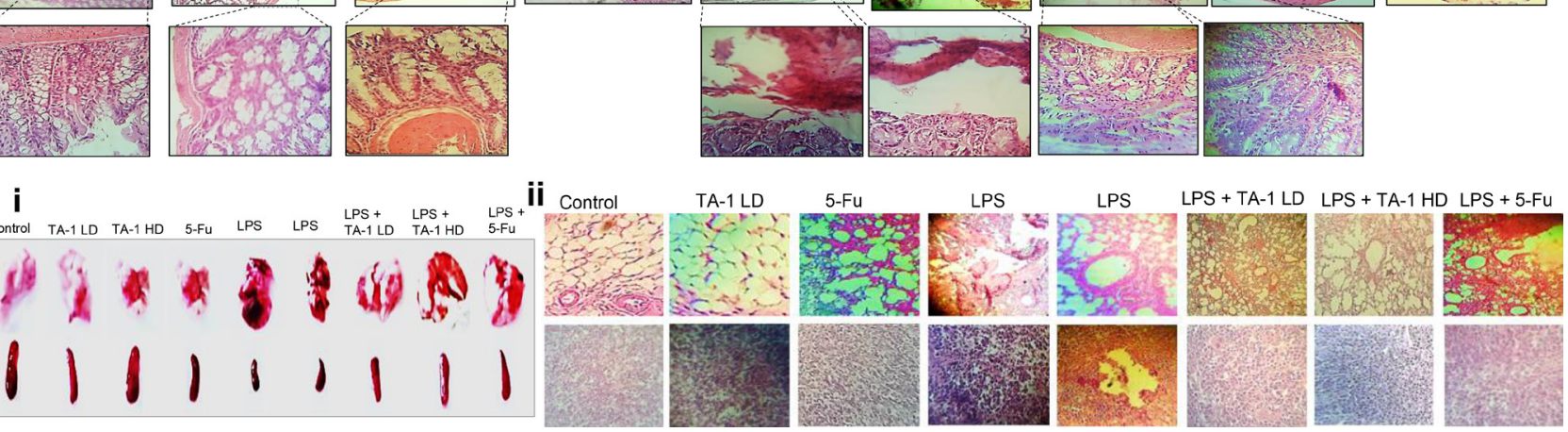

Figure 8: (A) Experimental strategy of the model with days of exposure to LPS and proposed therapy with essential oil; (B) animals weight during treatment; (C) macroscopical view of mice colon (i) and colon lenght (ii) of each group; (D) microscopical analysis of colon tissues of TA-1 (LD) group (a), TA-1 (HD) group (b), 5-Fu group (c), LPS group (d, e and f), LPS + TA-1 group (g, h), and LPS + 5-Fu group (i). (E) macroscopical view (i) and the histological overview (ii) of lung and spleen of different groups. TA-1: Teucrium alopecurus essential oil; LD: low dose; HD: high dose; 5-Fu: 5-Fluorouracil; LPS: Lipopolysaccharides. 
Co.; Butyl-hydroxytoluene (BHT), Ascorbic acide (1\%), 2,2-diphényl-1-picrylhydrazyl (DPPH), ferric reducing antioxidant power (FRAP), Potassium ferricyanide $\left(\mathrm{K}_{3} \mathrm{Fe}(\mathrm{CN})_{6}\right)(1 \%)$, Trichloro acetic acide (TCA) $(10 \%)$, Ferric Chloride $\left(\mathrm{FeCl}_{3}\right)(0.1 \%)$, CFM $(10 \mu \mathrm{g} / \mu \mathrm{l})$, and ERTA $(10 \mu \mathrm{g} / \mu \mathrm{l})$ were obtained from Sigma-Aldrich Chemicals Co. (St. Louis, MO, USA).

\section{Cell lines}

The cell lines HCT-116, MiaPaca-2 (Human pancreatic carcinoma), Panc28, KBM-5, SCC4 (human head and neck cancer), MCF7, U266 (human multiple myeloma), HL-60 (human promyelocytic leukemia), RAW 264.7 (mouse monocyte macrophage) and HUVECs were obtained from the American Type Culture Collection (Manassas, VA, USA). Human colon cancer cells, human pancreatic carcinoma, pancreatic carcinoma, human head and neck cancer, and RAW cells were cultured in Dulbecco's modified Eagle's medium (DMEM) supplemented with $10 \%$ fetal bovine serum (FBS). HL-60 and U266 cells were cultured in RPMI-1640 medium with $10 \%$ FBS; KBM-5 cells were cultured in Iscove's modified Dulbecco's medium (IMDM) supplemented with $15 \%$ FBS; and MCF-7 cell lines were cultured in DMEM/F12 with $10 \%$ FBS and no antibiotics. HUVECs cells were cultured in DMEM containing 10\% FBS. All culture media were supplemented with $100 \mathrm{U} / \mathrm{mL}$ penicillin and $100 \mu \mathrm{g} / \mathrm{mL}$ streptomycin.

\section{Tested bacteria}

The bacteria used in this study including Escherichia coli (E.coli), Staphylococcus aureus (S.aureus), Bacillus subtilis (B.subtilis), and Klebsiella pneumoniae (K.pneumoniae) were obtained from the laboratory of microbiology, Gafsa Hospital, Tunisia.

\section{Analysis of oily and hydrophilic fractions of Teucrium alopecurus by gas chromatography- mass spectrometry}

Teucrium alopecurus leaves were collected from Orbata Mountain, Gafsa, Tunisia. A voucher specimen was deposited in the National Institute of Agronomic of Tunisia (INAT) Herbarium in Tunisia under registration number 1122. Decanted essential oil was separated, and the hydrosol was collected from the Clevenger distiller apparatus. To profile Teucrium essential oil and hydrosol bioactive compounds, GC/MS analysis was used. Different fractions were analysed using gas chromatography coupled with mass spectrometry (GC-MS) on an Agilent 6890 gas chromatograph with an autosampler coupled with an Agilent 5973 Mass Selective Detector (MSD) detector (Agilent Technologies, Palo Alto, CA, USA) with an electron impact ionization of $70 \mathrm{eV}$. A Phenomenex ZB-
5MSi capillary column $(30 \mathrm{~m} \times 0.25 \mathrm{~mm}, 0.5 \mu \mathrm{m}$ film thickness; Agilent Technologies, Hewlett-Packard, CA, USA) was used at a temperature programmed to rise from 40 to $280^{\circ} \mathrm{C}$ at a rate of $5^{\circ} \mathrm{C} / \mathrm{min}$. Helium $(99.999 \%$ purity) was used as a gas carrier, with a flow rate of $0.7 \mathrm{~mL} / \mathrm{min}$, a split ratio of $60: 1$, and a scan time and mass range of $1 \mathrm{~s}$ and $50-550 \mathrm{~m} / \mathrm{z}$, respectively. EOs were identified by matching the mass spectra recorded with those stored in the Wiley 09 NIST 2011 mass spectral library of the $\mathrm{GC} / \mathrm{MS}$ data system.

\section{Phenolic content and antioxidant activity}

Phenolic and flavonoid content were determined based on the method of Singleton and Rossi [60] and Dewanto et al. [61], respectively.

To verify that the CFl can scavenge the DPPH radicals (DPPH), the modified DPPH method was measured as described by Brand-Williams et al. [62], using ascorbic acid as standard solution.

The evaluation of the ferric reducing antioxidant power (FRAP) of TA-1 and TA-2 was assessed by potassium ferricyanide-ferric chloride method as previously described by Oyaizu [63] with slight modifications, using BHT as standard solution.

\section{Disc diffusion assay}

The antibacterial activity of TA-1 was evaluated by disc diffusion assay as described by Vlietinck et al. [64].

\section{Cell viability assay}

RAW 264.7 ( $10^{5}$ cells/well) were seeded onto 96well plates and incubated with different concentrations of Teucrium essential oil $(0,0.5,1,5$, or $10 \mathrm{pg} / \mathrm{mL})$ and water soluble fractions of Teucrium $(0,30,50,70$, or $100 \mu \mathrm{g} / \mathrm{mL})$ dissolved in DMSO for 24, 48, or $72 \mathrm{~h}$. MTT solution was added and cells were incubated for $2 \mathrm{~h}$ at $37^{\circ} \mathrm{C}$. Absorbance was measured at $570 \mathrm{~nm}$ using an MRX Revelation 96-well multiscanner (Dynex Technologies, Chantilly, VA, USA).

\section{Antiproliferative effect of TA-1}

The antiproliferative effect of TA-1 was assessed by MTT assay as previously described [65]. $5 \times 10^{2}$ cells per well were incubated with different concentrations of Teucrium essential oil $(0,0.5,1,5$, or $10 \mathrm{pg} / \mathrm{mL})$ and water soluble fractions of Teucrium $(0,30,50,70$, or $100 \mu \mathrm{g} / \mathrm{mL}$ ) dissolved in DMSO for one, three, or five days in 96-well plates. Vehicle was considered as control. After treatment, the MTT solution was added to various tumor cells, which were incubated for $2 \mathrm{~h}$ at $37^{\circ} \mathrm{C}$ before adding the extraction buffer. The cells were incubated 
overnight at $37^{\circ} \mathrm{C}$. Absorbance was measured at $570 \mathrm{~nm}$ using an MRX Revelation 96-well multiscanner (Dynex Technologies, Chantilly, VA, USA).

\section{Live/dead assay}

Apoptosis was measured by Live/Dead assay, which determines the number of live and dead cells. After the treatment of various tumor cells $\left(2 \times 10^{5}\right)$ with 0.0005 , $0.001,0.005,0.01$, or $0.05 \mathrm{pg} / \mathrm{mL}$ of TA-1 and 3.75, 5, 10 , or $15 \mu \mathrm{g} / \mathrm{mL}$ of TA-2, the treated cells and untreated cells were stained with a a green fluorescent dye, a nonfluorescent polyanionic dye, calcein-AM, which is retained within live cells, and Ethidium homodimer dye, a red fluorescent that can enter cells through damaged membranes, and the cells were incubated for $30 \mathrm{~min}$ at $37^{\circ} \mathrm{C}$. The cells were analyzed under a fluorescence microscope (Labophot-2; Nikon, Melville, NY, USA). After counting the live and dead cells, the percentage of cells in apoptosis in each sample was calculated.

\section{Clonogenic assay}

To determine tumor growth, a clonogenic assay was done. The cells were treated with different concentrations of TA- 1 and TA-2, and then the treated and untreated cells were seeded in Petri dishes, allowed to form colonies for two weeks, and then stained, as indicated by Takada and Aggarwal [65].

\section{Production of ROS levels in HCT116}

Colon cancer cells $\left(1 \times 10^{6}\right.$ cells $)$ cells were labeled with dichlorodihydrofluorescein diacetate (DCF-DA) (20 $\mu \mathrm{M})$ and exposed to different concentrations of oily and soluble fractions of Teucrium species for $1 \mathrm{~h}$. The increase in fluorescence resulting from the oxidation of DCF-DA to DCF was measured by fluorescence-activated cell sorting (FACS). The mean fluorescence intensity at $530 \mathrm{~nm}$ was calculated. The results were collected from at least 10,000 cells at a flow rate of $250-300$ cells $\cdot \mathrm{s}^{-1}[66]$.

\section{Western blot analysis}

Western blotting is used for the detection and analysis of proteins based on their ability to bend to specific antibodies. Cell extracts (treated and untreated cancer cells, normal cells) were prepared in lysis buffer (20 mM, Tris ( $\mathrm{pH} 7.4), 250 \mathrm{Mm} \mathrm{NaCl}, 2 \mathrm{Mm}$ ethylenediaminetetraacetic acid (EDTA) ( $\mathrm{pH}$ 8.0), $0.1 \%$ triton $\mathrm{X}-100,0.01 \mu \mathrm{g} / \mathrm{mL}$ aprotinin, $0.005 \mu \mathrm{g} / \mathrm{mL}$ leupeptin, $0.4 \mathrm{M}$ phenylmethylsulfonyl fluoride, and $4 \mathrm{Mm}$ $\mathrm{Na}_{3} \mathrm{VO}_{4}$ ). To remove insoluble materials, we centrifuged lysates at $1400 \mathrm{rpm}$ for $10 \mathrm{~min}$. The supernatant was collected and kept at $-80^{\circ} \mathrm{C}$. Thirty $\mu \mathrm{g}$ of lysates were resolved by $10 \%$ SDS-PAGE and the proteins were then transferred to nitrocellulose membranes where they were bound, forming the blot. After that, the membranes were probed overnight with relevant primary antibodies at $4^{\circ} \mathrm{C}$. After the blotting process, the proteins were exposed to a thin surface layer for primary antibody detection. The dilution factors of antibodies are: c-Myc (1:2000), CXCR4 (1:5000), MMP-9 (1:1000), cIAP-1/2 (1:2000), Mcl-1 (1:3000), ICAM-1 (1:2000), Bcl-xL (1:2000), cyclin D1 (1:3000), caspase-3 (1:2000), -8 (1:2000) and -9 (1:2000), PARP (1:5000), Bcl-2 (1:3000), STAT-3 (1:3000), pSTAT3 (Tyr705 and Ser727) (1:2000), $\beta$-actin $(1: 10,000)$, XIAP (1:3000), c-FLIP (1:3000), survivin (1:2000), VEGF (1:1000), p53 (1:3000), and TRAF1 (1:2000).

Then, blots, blocked with $5 \%$ nonfat milk, were incubated with peroxidase-conjugated secondary antibodies (goat anti-mouse or goat anti-rabbit) (1:5000) diluted in 5\% skimmed milk for $1 \mathrm{~h}$, and signals were detected by enhanced chemiluminescence reagent (GE Healthcare, Piscataway, NJ, USA). Vehicle was considered as control. The bands obtained were quantitated using NIH imaging software (Available online: https://imagej.nih.gov/ij/download.html).

\section{Acute toxicity test}

To evaluate the cytoxicity effect of TA-1, four groups of mice (6 mice per group), obtained from the experimental animal house, sfax, Tunisia, were given standard pellets and tap water and treated with increasing doses of the essential oil $(0-10-20-30 \mu \mathrm{g} / \mathrm{kg})$. The essential oil administration was prepared by diluting the stock solution of TA-1 by mixing it with $2 \%$ Tween 80 . After treatment, the animals were kept under observation daily for any behavioral changes, mortality or consumption of food and water. After 7 days, the mice were euthanized, and the liver and kidney tissues were used for macroscopically and histological overview.

\section{In vivo antitumour activity}

\section{Animal studies}

A total of 48 Swiss albino mice $(20 \pm 1.00 \mathrm{~g})$ were obtained from the Animal laboratory of Sfax, Tunisia. Mice were maintained for a week in a propylene cage at $20 \pm 25^{\circ} \mathrm{C}$ with relative humidity of $55 \% \pm 10 \%$ under a cycle of $12 \mathrm{~h}$ light/dark. Animals were allowed ad libitum to access to tap water and food pellets.

\section{Experimental procedures}

The essential oil used in this report was dissolved in $2 \%$ Tween 80 and given to mice intragastrically once a day for 7 consecutive days. At the beginning of the experiment, the mice were divided into eight groups (6 mice per group) as follows: Group $1:$ mice treated by intragastrically administration of vehicle ( $2 \%$ Tween 80 in distilled water); Group 2: served as positive (tumor) control, mice treated by intragastrically administration 
of LPS (Escherichia coli 055:B5) (10 $\mu \mathrm{g} / \mathrm{ml})$; Group 3: animals treated by intragastrically administration of the essential oil $(10 \mu \mathrm{g} / \mathrm{kg} /$ day $)$; Group 4: mice treated by intragastrically administration of the essential oil (20 $\mu \mathrm{g} / \mathrm{kg} /$ day). The treatments were started daily, one hours before LPS treatment; Group 5: served as comparator control, mice treated by intragastrically administration of 5-fluorouracil (5-FU) $(20 \mathrm{mg} / \mathrm{kg} /$ day $)$. Group 6: TA-1 LD combined with LPS (TA-1 LD + LPS) $(10 \mu \mathrm{g} / \mathrm{kg}$, body weight/day and $10 \mu \mathrm{g} / \mathrm{ml}$, respectively); Group 7: TA-1 HD combined with LPS (TA-1 HD + LPS) $(20 \mu \mathrm{g} /$ $\mathrm{kg}$, body weight/day and $10 \mu \mathrm{g} / \mathrm{ml}$, respectively); Group 8: 5 -Fu combined with LPS (5-Fu + LPS) $(20 \mathrm{mg} / \mathrm{kg}$, body weight/day and $10 \mu \mathrm{g} / \mathrm{ml}$, respectively). All the treatments were given orally once daily for 7 days. After 7 days, the mice were euthanized; lung, spleen and colonic tissues were collected to be analyzed macroscopically and microscopically by Hematoxylin \& Eosin staining. The experiments were carried out according to Guide for the Care and Use of laboratory Animals approved by the Animal Ethics Committee.

\section{Statistical analysis}

Different parameters were monitored in normal and treated cells. Experiments were repeated a minimum of three times. The results were expressed as mean $\pm \mathrm{SD}$. Differences between groups were compared by a one-way analysis of variance (ANOVA). A value of $p<0.05$ was considered statistically significant.

\section{Abbreviations}

MTT: Tetrazolium salt 3-(4-5-dimethylthiozol2-yl)2-5-diphenyl-tetrazolium bromide;VEGF: Antivascular endothelial growth factor;Bcl-xL: B-cell leukemia protein xL;cIAP: Cellular inhibitor of apoptosis protein;PARP: Poly-adenosine diphosphate ribose polymerase;c-FLIP: Cellular FLICE-inhibitory protein;XIAP: X-linked IAP;ICAM-1: Intercellular adhesion molecule-1;CXCR4: CXC chemokine receptor4;FLICE: FADD-like IL-1 $\beta$-converting enzyme;ROS: Reactive Oxygen Species;STAT3: Signal transducer and activator of transcription 3;TRAF: TNF receptorassociated factor.

\section{Author contributions}

Fatma Guesmi performed the experiments and wrote the article. Sahdeo Prasad and Amit Kumar Tyagi drafted and revised the manuscript. All authors read and approved the final manuscript.

\section{ACKNOWLEDGMENTS}

We would like to thank Bharat B. Aggarwal, Founding Director, Inflammation Research Institute, San Diego, CA, USA and Former Professor of Experimental Therapeutics, Cancer Medicine and Immunology, The University of Texas M. D. Anderson Cancer Center, Houston, TX, USA.

\section{CONFLICTS OF INTEREST}

None.

\section{REFERENCES}

1. Gupta SC, Kim JH, Prasad S, Aggarwal BB. Regulation of survival, proliferation, invasion, angiogenesis, and metastasis of tumor cells through modulation of inflammatory pathways by nutraceuticals. Cancer Metastasis Rev. 2010; 29:405-434.

2. de Sousa DP. Bioactive Essential Oils and Cancer. Springer International Publishing Switzerland. 2015.

3. Yadav VR, Prasad S, Sung B, Gelovani JG, Guha S, Krishnan S, Aggarwal BB. Boswellic Acid Inhibits Growth and Metastasis of Human Colorectal Cancer in Orthotopic Mouse Model By Downregulating Inflammatory, Proliferative, Invasive, and Angiogenic Biomarkers. Int J Cancer. 2012; 130:2176-2184.

4. Prasad S, Gupta SC, Aggarwal BB. Serendipity in Cancer Drug Discovery: Rational or Coincidence? Trends Pharmacol Sci. 2016; 37:435-50.

5. Aggarwal BB, Prasad S, Sung B, Krishnan S, Guha S. Prevention and Treatment of Colorectal Cancer by Natural Agents from Mother Nature. Curr Colorectal Cancer Rep. 2013; 9:37-56.

6. Fu Q, Jiang Y, Zhang D, Liu X, Guo J, Zhao J. Valosincontaining protein (VCP) promotes the growth, invasion, and metastasis of colorectal cancer through activation of STAT3 Signalling. Mol Cell Biochem. 2016; 418:189-198.

7. Ivanova D, Bakalova DR, Lazarova D, Gadjeva V, Zhelev Z. The Impact of Reactive Oxygen Species on Anticancer Therapeutic Strategies. Adv Clin Exp Med. 2013; 22:899-908.

8. Yu JQ, Lei JC, Zhang XQ, Yu HD, Tian DZ, Liao ZX, Zou GL. Anticancer, antioxidant and antimicrobial activities of the essential oil of Lycopus lucidus Turcz. var. hirtus Regel. Food Chem. 2011; 126:1593-1598.

9. Mitoshi M, Kuriyama I, Nakayama H, Miyazato H, Sugimoto K, Kobayashi Y, Jippo T, Kanazawa K, Yoshida H, Mizushina Y. Effects of essential oils from herbal plants and citrus fruits on DNA polymerase inhibitory, cancer cell growth inhibitory, antiallergic, and antioxidant activities. J Agric Food Chem. 2012; 60:11343-11350. 
10. Gautam N, Mantha AK, Mittal S. Essential Oils and Their Constituents as Anticancer Agents: A Mechanistic View. BioMed Res Int. 2014; 2014:154106.

11. Cha JD, Kim YH, Kim JY. Essential oil and 1,8-cineole from Artemisia lavandulaefolia induces apoptosis in KB Cells via mitochondrial stress and caspase activation. Food Sci Biotechnol. 2010; 19:185-191.

12. Jayaprakasha GK, Murthy KNC, Uckoo RM, Patil BS. Chemical composition of volatile oil from Citrus limettioides and their inhibition of colon cancer cell proliferation. Ind Crops Prod. 2013; 45:200-207.

13. Gomes MRF, Schuh RS, Jacques ALB, Augustin OA, Bordignon SAL, Dias DO, Kelmann RG, Koester LS, Gehring MP, Morrone FB, Campos MM, Limberger RP. Cytotoxic activity evaluation of essential oils and nanoemulsions of Drimys angustifolia and D. brasiliensis on human glioblastoma (U-138 MG) and human bladder carcinoma (T24) cell lines in vitro. Braz J Pharmacog. 2013; 23:259-267.

14. Nanyonga SK, Opoku A, Lewu FB, Oyedeji AO, Singh M. Chemical composition, antioxidant activity and cytotoxicity of the essential oils of the leaves and stem of Tarchonanthus camphorates. Afr J Pharm Pharmacol. 2013; 7:360-367.

15. Akrout A, Gonzalez LA, El Jani H, Madrid PC. Antioxidant and antitumor activities of Artemisia campestris and Thymelaea hirsuta from southern Tunisia. Food Chem Toxicol. 2011; 49:342-347.

16. $\mathrm{Zu} \mathrm{Y,} \mathrm{Yu} \mathrm{H,} \mathrm{Liang} \mathrm{L,} \mathrm{Fu} \mathrm{Y,} \mathrm{Efferth} \mathrm{T,} \mathrm{Liu} \mathrm{X,} \mathrm{Wu} \mathrm{N.}$ Activities of ten essential oils towards Propionibacterium acnes and PC-3, A-549 and MCF-7 cancer cells. Molecules. 2010; 15:3200-3210.

17. Ferraz RP, Cardoso GM, da Silva TB, Fontes JE, Prata AP, Carvalho AA, Moraes MO, Pessoa C, Costa EV, Bezerra DP. Antitumour properties of the leaf essential oil of Xylopia frutescens Aubl. (Annonaceae). Food Chem. 2013; 141:196-200.

18. Russo R, Ciociaro A, Berliocchi L, Cassiano MGV, Rombolà L, Ragusa S, Bagetta G, Blandini F, Corasaniti MT. Implication of limonene and linalyl acetate in cytotoxicity induced by bergamot essential oil in human neuroblastoma cells. Fitoterapia. 2013; 89:48-57.

19. Jo JR, Park JS, Park YK, Chae YZ, Lee GH, Park GY, Jang BC. Pinus densiflora leaf essential oil induces apoptosis via ROS generation and activation of caspases in YD-8 human oral cancer cells. Int J Oncol. 2012; 40:1238-45.

20. Edris AE. Anti-cancer properties of Nigella spp. essential oils and their major constituents, thymoquinone and betaelemene. Curr Clin Pharmacol. 2009; 4:43-6.

21. Sylvestre M, Pichette A, Longtin A, Nagau F, Legault J. Essential oil analysis and anticancer activity of leaf essential oil of Croton flavens L. from Guadeloupe. J Ethnopharmacol. 2006; 103:99-102.
22. Miguel MG. Antioxidant and Anti-Inflammatory Activities of Essential Oils: A Short Review. Molecules. 2010; 15:9252-9287.

23. Shanmugam MK, Nguyen AH, Kumar AP, Tan BK, Sethi G. Targeted inhibition of tumor proliferation, survival, and metastasis by pentacyclic triterpenoids: potential role in prevention and therapy of cancer. Cancer Lett. 2012; 320:158-170.

24. Tutin TG, Heywood VH, Burges NA, Moore DM, Valentine DH, Webb DA. Flora Europaea. Cambridge: Cambridge University Press. 1976; 3: 129-35.

25. Rajabalian S. Methanolic extract of Teucrium polium L. potentiates the cytotoxic and apoptotic effects of anticancer drugs of vincristine, vinblastine and doxorubicin against a panel of cancerous cell lines. Exp Oncol. 2008; 30:133-138.

26. Movahedi A, Basir R, Rahmat A, Charaffedine M, Othman F. Remarkable Anticancer Activity of Teucrium polium on Hepatocellular Carcinogenic Rats. Evid Based Complement Alternat Med. 2014; 2014:726724.

27. Prakobwong S, Gupta SC, Kim JH, Sung B, Pinlaor P, Hiraku Y, Wongkham S, Sripa B, Pinlaor S, Aggarwal BB. Curcumin suppresses proliferation and induces apoptosis in human biliary cancer cells through modulation of multiple cell signaling pathways. Carcinogenesis. 2011; 32:1372-1380.

28. Noureini SK, Esmaeili H, Abachi F, Khiali S, Islam B, Kuta M, Saboury AA, Hoffmann M, Sponer J, Parkinson G, Haider S. Selectivity of major alkaloids from chelidonium majus towards telomeric G-quadruplex: A study using a transition-FRET (t-FRET) assay. Biochim Biophys Acta. 2017; 1861:2020-2030.

29. Menichini F, Conforti F, Rigano D, Formisano C, Piozzi F, Senatore F. Phytochemical composition, anti-inflammatory and antitumour activities of four Teucrium essential oils from Greece. Food Chem. 2009; 115:679-686.

30. Hachicha S, Skanji T, Barrek S, Zarrouk H, Ghrabi ZG. Chemical Composition of Teucrium alopecurus Essential Oil from Tunisia. J Essent Oil Res. 2007; 19:413-415.

31. Hachicha SF, Barrek S, Skanji T, Zarrouk H, Ghrabi ZG. Fatty acid, tocopherol, and sterol content of three Teucrium species from Tunisia. Chem Nat Compd. 2009; 45:304-308.

32. Sharma A, Bajpai VK, Shukla S. Sesquiterpenes and Cytotoxicity. Nat Prod Springer. 2013:3515-50.

33. Tilaoui M, Mouse HA, Jaafari A, Zyad A. Differential Effect of Artemisinin Against Cancer Cell Lines. Nat Prod Bioprospect. 2014; 4:189-196.

34. Santoro GF, Das Gracas Cardoso M, Guimaraes LG, Salgado AP, Menna-Barreto RF, Soares MJ. Effect of Oregano (Origanum vulgare L.) and Thyme (Thymus vulgaris L.) essential oils on Trypanosoma cruzi (Protozoa: Kinetoplastida) growth and ultrastructure. Parasitol Res. 2007; 100:783-790. 
35. Schnitzler P, Koch C, Reichling J. Susceptibility of drugresistant clinical HSV-1 strains to essential oils of Ginger, Thyme, Hyssop and Sandalwood. Antimicrob Agents Chemother. 2007; 51:1859-1862.

36. El Hadri A, Del Río MG, Sanz J, Coloma AG, Idaomar M, Ozonas BR, González JB, Reus MS. Cytotoxic activity of $\alpha$-humulene and transcaryophyllene from Salvia officinalis in animal and human tumor cells. An R Acad Nac Farm. 2010; 76:343-356.

37. Sobral MV, Xavier AL, Lima TC, de Sousa DP. Antitumor Activity of Monoterpenes Found in Essential Oils. Sci World J. 2014; 2014:953451.

38. Tilaoui M, Ait Mouse H, Jaafari A, Zyad A. Comparative Phytochemical Analysis of Essential Oils from Different Biological Parts of Artemisia herba alba and Their Cytotoxic Effect on Cancer Cells. PLoS One. 2015; 10:e131799.

39. Yin QH, Yan FX, Zu XY, Wu YH, Wu XP, Liao MC, Deng SW, Yin LL, Zhuang YZ. Anti-proliferative and pro-apoptotic effect of carvacrol on human hepatocellular carcinoma cell line HepG-2. Cytotechnology. 2012; 64:43-51.

40. Tyagi AK, Prasad S, Yuan W, Li S, Aggarwal BB. Identification of a novel compound ( $\beta$-sesquiphellandrene) from turmeric (Curcuma longa) with anticancer potential: Comparison with curcumin. Invest New Drugs. 2015; 33:1175-86.

41. Escandary H, Rajabalian S, Yazdi T, Escandari M, Fatehi K, Ganjooei NA. Evaluation of cytotoxic effect of Teucrium polium on a new glioblastoma multiforme cell line (REYF-1) using MTT and soft agar clonogenic assays. Int J Pharm. 2007; 3:435-437.

42. Vinall RL, Hwa K, Ghosh P, Pan CX, Lara PN Jr, de Vere White RW. Combination treatment of prostate cancer cell lines with bioactive soy isoflavones and perifosine causes increased growth arrest and/or apoptosis. Clin Cancer Res. 2007; 13:6204-16.

43. Kruidering M, Evan GI. Caspase- 8 in Apoptosis: The Beginning of "The End"? IUBMB Life. 2000; 50:85-90.

44. Jia SS, Xi GP, Zhang M, Chen YB, Lei B, Dong XS, Yang YM. Induction of apoptosis by D-limonene is mediated by inactivation of Akt in LS174T human colon cancer cells. Oncol Rep. 2013; 29:349-54.

45. King KL, Cidlowski JA. Cell cycle regulation and apoptosis. Annu Rev Physiol. 1998; 60:601-617.

46. Kwon SK, Saindane M, Baek KH. p53 stability is regulated by diverse deubiquitinating enzymes. Biochim Biophys Acta. 2017; 1868:404-411.

47. Gupta SC, Prasad S, Sethumadhavan DR, Nair MS, Mo YY, Aggarwal BB. Nimbolide, a Limonoid Triterpene, Inhibits Growth of Human Colorectal Cancer Xenografts by Suppressing the Proinflammatory Microenvironment. Clin Cancer Res. 2013; 19:4465-4476.

48. Bhutani M, Pathak AK, Nair AS, Kunnumakkara AB, Guha S, Sethi G, Aggarwal BB. Capsaicin Is a Novel Blocker of Constitutive and Interleukin-6-Inducible STAT3 Activation. Clin Cancer Res. 2007; 13:3024-32.
49. Li Q, Zhang D, Chen X, He L, Li T, Xu X, Li M. Nuclear PKM2 contributes to gefitinib resistance via upregulation of STAT3 activation in colorectal cancer. Sci Rep. 2015; 5:16082.

50. Vendramini-Costa DB, Carvalho JE. Molecular link mechanisms between inflammation and cancer. Curr Pharm Des. 2012; 18:3831-3852.

51. Chidambara KN, Jayaprakasha GK, Shivappa Mantur MB. Citrus monoterpenes: potential source of phytochemicals for cancer prevention. Em erging Trends in Dietary Components for Preventing and Combating Disease. 2010; 31:545-58.

52. Jung YD, Kim MS, Shin BA, Chay KO, Ahn BW, Liu W, Bucana CD, Gallick GE, Ellis LM. EGCG, a major component of green tea, inhibits tumour growth by inhibiting VEGF induction in human colon carcinoma cells. Br J Cancer. 2001; 84:844-850.

53. Kitamura T, Pollard JW. Therapeutic potential of chemokine signal inhibition for metastatic breast cancer. Pharmacol Res. 2015; 100:266-270.

54. Deb DD, Parimala G, Saravana DS, Chakraborty T. Effect of thymol on peripheral blood mononuclear cell PBMC and acute promyelotic cancer cell line HL-60. Chem Biol Interact. 2011; 193:97-106.

55. Huang FC, Fan Y, Zheng S. Effect of elemene on the telomerase activity, apoptosis and cell cycles of the colon cancer lovo cell line. Herald Med. 2004; 10:713-715.

56. Kawamori T, Tanaka T, Hirose Y, Ohnishi M, Mori H. Inhibitory effects of d-limonene on the development of colonic aberrant crypt foci induced by azoxymethane in F344 rats. Carcinogenesis. 1996; 17:369-372.

57. Sassi N, Mattarei A, Espina V, Liotta L, Zoratti M, Paradisi C, Biasutto L. Potential anti-cancer activity of 7-O-pentyl quercetin: Efficient, membrane-targeted kinase inhibition and pro-oxidant effect. Pharmacol Res. 2017; 124:9-19.

58. Li S, Xu X, Jiang M, Bi Y, Xu J, Han M. Lipopolysaccharide induces inflammation and facilitates lung metastasis in a breast cancer model via the prostaglandin E2-EP2 pathway. Mol Med Rep. 2015; 11:4454-4462.

59. Ying J, Zhou HY, Liu P, You Q, Kuang F, Shen YN, Hu ZQ. Aspirin inhibited the metastasis of colon cancer cells by inhibiting the expression of toll-like receptor 4. Cell Biosci. 2018; 8:1.

60. Singleton VL, Rossi JA. Colorimetry of total phenolics with phosphomolybdicphosphotungstic acid reagents. Am J Enol Vitic. 1965; 16:144-58.

61. Dewanto V, Wu X, Adom KK, Liu RH. Thermal processing enhances the nutritional value of tomatoes by increasing total antioxidant activity. J Agric Food Chem. 2002; 50:3010-3014.

62. Brand-Williams W, Cuvelier ME, Berset C. Use of a free radical method to evaluate antioxidant activity. Food Sci Technol. 1995; 28:25-30. 
63. Oyaizu M. Studies on products of browning reactions: antioxidant activities of products of browning reaction prepared from glucosamine. Japan J Nutrit. 1986; 44:307-315.

64. Vlietinck AJ, Van Hoof L, Totté J, Lasure A, Vanden Berghe D, Rwangabo PC, Mvukiyumwami J. Screeening of hundred Rewandese medicinal plants for antimicrobial and antiviral properties. J Ethnopharmacol. 1995; 46:31-47.

65. Takada Y, Aggarwal BB. Betulinic acid suppresses carcinogen-induced NF-kappa B activation through inhibition of I kappa B alpha kinase and p65 phosphorylation: abrogation of cyclooxygenase-2 and matrix metalloprotease-9. J Immunol. 2003; 171:3278-86.

66. Prasad S, Ravindran J, Sung B, Pandey MK, Aggarwal BB. Garcinol potentiates TRAIL-induced apoptosis through modulation of death receptors and antiapoptotic proteins. Mol Cancer Ther. 2010; 9:856-68. 